\title{
IS THIS FOR REAL? AUTHENTIC LEARNING FOR THE CHALLENGING EVENTS ENVIRONMENT
}

\author{
Martin Robertson * MA, BA (Hons), ILT \\ Lecturer \\ martin.robertson@vu.edu.au \\ Olga Junek MBus, BA, DipEd \\ Lecturer \\ olga.junek@vu.edu.au \\ Leonie Lockstone-Binney PhD \\ Senior Lecturer \\ leonie.lockstone@vu.edu.au \\ School of International Business \\ Victoria University \\ PO Box 14428 \\ Melbourne Australia 8001 \\ * Corresponding author
}

\begin{abstract}
This article explores a set of emerging competencies that education providers will be increasingly compelled to consider, and more importantly, embed in their event management course offerings. The undergraduate event management program offered at Victoria University, Melbourne, provides a case study of the efforts of teaching staff to iteratively and reflectively integrate these emerging competencies into course curriculum, many of which will be required for graduates to successfully transition to work in their career sector of choice, the events industry. The competencies of sustainable development, creativity and innovation and networking are all seen as vital to graduate outcomes and employability. The fundamental responses to this process are discussed leading to a distillation of the implications for teaching practice associated with embedding emerging competencies in event management education.
\end{abstract}

KEY WORDS: competencies, event management, student learning

RUNNING HEAD: AUTHENTIC LEARNING FOR THE CHALLENGING EVENTS ENVIRONMENT

This article has not been published elsewhere and it has not been submitted simultaneously for publication elsewhere. 


\section{INTRODUCTION}

This article presents an exploratory study investigating a set of emerging competencies that will be increasingly aligned with event management education over the coming years. The undergraduate event management program offered at Victoria University, Melbourne provides a case study of the efforts of teaching staff to identify and integrate these emerging competencies into the course curriculum, competencies that will be required for graduates to successfully transition into their ensuing event management careers.

The article will investigate fundamental responses to this process and associated challenges. These will be examined as part of an informed discussion on how to embed emerging competencies, which may not currently be viewed as vital by students or industry. Some background to the case, in terms of study location, authentic learning and an overview of the needs of students and industry related to event management education, is initially provided to contextualise this discussion.

\section{BACKGROUND}

\section{Study location}

Melbourne is a city renowned for many major events. Events such as the 2006 Commonwealth Games, the 2007 FINA World Swimming Championships, together with the ongoing hosting of the Australian Open (Tennis Championship) and the Australian Formula One Grand Prix attest to this well deserved reputation. Allowing students to capitalise on these living examples, Victoria University, Melbourne, has been at the forefront of event management education in Australia, offering a stand-alone degree in the area of study since 2003.

The core product, the Bachelor of Business specialising in Event Management, can be combined with one of a number of the other disciplinary areas such as tourism, hospitality, marketing and law. Within the course students study generic business subjects as well as seven event management specialisation subjects that focus on event operations, sustainable management, creation and design aspects, event evaluation, business events and live performance management. In addition to their university subjects, students also complete a compulsory component of work integrated learning. This can take the form of Co-operative Education, which is an industry placement in fulltime paid employment for one year, or Business Integrated learning, which comprises 150 hours, spent working in industry on either a paid or voluntary basis. Students also take seven elective units of study of their choosing.

Given it represents and reflects an emerging area of study, the course content and delivery of Victoria University's event management degree has been the focus of a number of pedagogical related research projects/publications in recent years. Junek, Lockstone and Mair (2009) examined the requisite skills and abilities students perceive to be associated with event management employment and employers' assessments of where students stand in relation to these skills. The findings of this study suggest that educators need to more closely align student perceptions of the importance and their subsequent performance in certain skill areas with event industry standards. An earlier case study of industry engagement in event management education by Mair, Junek and Lockstone (2009), using evaluative data and reflections from the teaching staff, identified the key benefits of bringing industry into the classroom including giving students the opportunity to network with industry professionals, and enabling increased contextualisation of learning. The study concludes that these benefits for students, academic staff, industry and the university as a whole outweigh the associated challenges of effective classroom industry engagement including the opportunity cost of staff time required to organise engagement opportunities, speaker management and reliability and the need to incentivise student attendance.

\section{Authentic learning and business education: An introduction}

Discussions about authentic learning and its increasing importance and place in the higher education curriculum have focused on a number of aspects of learning in the workplace and community (Power 2010; Stein, Isaacs \& Andrews, 2004; Tochon, 2000), learning tied to specific cultural practices (Brown, Collins \& Duguid, 1988; Bruner, 1996; Van Oers \& Wardekker, 1999) and simulation practices for authentic learning (Diamond, Middleton \& Maher, 2011). 
In business studies (of which event management education is an area of study), authentic learning aims to bridge the gap between what is taught as the theoretical underpinnings of business courses and the practical aspects of the business world. In a sense, authentic learning aims to provide real-world practical experience within a safe and non-threatening learning environment (Brown et al.1988), allowing students to participate within real communities of practice (Lave \& Wenger, 1991). Authentic learning as a concept has progressed in recent years with a focus on authentic assessment (Boud \& Falchikov, 2005; Fook \& Sidhu, 2010; Guilkers, Bastiens \& Kirschner, 2004; Mueller, 2006). In the literature on authentic assessment it is seen as mandatory that students are equipped with the "skills and competencies needed to succeed in today's workplace" (Fook \& Sidhu, 2010, p. 154). Student employability and embedded pedagogical practices based on employer input have also been discussed in this context (Harvey \& Locke, 2002; Diamond et al. 2011).

As globalisation, technology and financial challenges all play their part in transforming the business practices of today, students will need to be ready to adapt to global competition, a rapidly changing business environment and possible global crises. The knowledge, skills and competencies that they take with them from higher education will need to be such that they are able to function effectively in this 'new' business world. In the area of event management in particular, this will mean graduates who are able to plan, execute and evaluate events of all kinds and dimensions but also be capable of "custom designing highly targeted event experiences" (Getz, 2008, p. 421). It is for these reasons that event management graduates will need to take with them established as well as emerging competencies to be successful in this field. A brief overview of the established needs of the event management education sector follows.

\section{The recognised needs of students, industry and the event management education sector}

Event management courses at university level have gained in popularity and subsequent enrolments in the last decade (Silvers et al., 2006). They have become a popular choice for students who in the past may have enrolled in related areas such as tourism and hospitality. The events industry has also realised the importance of knowledgeable, skilled and well-trained professionals (Lee, Lee \& Kim, 2008).

A core and associated set of skills has been identified in relation to event management employment. Given the applied nature of the industry, understanding of the subject specialism, core skills, a personal belief of efficacy and the capacity to reflect on the learning process are key attributes acknowledged as influencing student employability (Beaven \& Wright, 2006). These attributes have been engaged in the design of an increasing number of vocational or semi-vocational degree curriculums. Moreover, it is agreed that these core skills required for employability need to be supplemented by a second set of content or industry specific skills (Christou, 2002; Junek et al. 2009).

In Griffiths and Guile's connective model (2003) these skills are attributed to "reflexivity; working collaboratively to apply and develop knowledge; poly contextual and connective skills and, developing partnerships with workplaces to create "environments for learning"' (p. 210).Their ideas resonate with those of Alderman and Milne's (2005) work placement model, which focuses on the link between theory and practice, and learning and experience. Akin to the earlier discussion of authentic learning, both articles emphasise the importance of students' application of learned concepts and theory to their work place (or practical) experience, and their subsequent ability to reflect on this relationship. This is seen as vital in developing not only competent, work-ready graduates, but also in co-creating opportunities for new knowledge and workplace practices.

The importance of student work experience in event management courses has been acknowledged by a number of authors (Beaven \& Wright, 2006; Moscardo \& Norris, 2004). Experiential learning has also been acknowledged by students as being highly beneficial to their studies within event management (Daruwalla \& Fallon, 2005) as well as other related areas such as sport management (Bennet, Henderson \& Drane, 2003).

There is consensus that higher education event management courses benefit from an experiential approach to curriculum design (Beaven \& Wright, 2006; Lockstone, Junek \& Mair, 2008; McDonald \& McDonald, 2000) to enhance both industry readiness and academic reflection. This latter point is vital, as is the students' capacity to reflect on their work. Reflection is what changes a mere experience to one that is a learning exercise. 
Whilst it is important to engage actively with industry to provide students with opportunities to participate in 'experiential learning', and the building up of practical skills and knowledge, it is also important to ensure this is done in a systematic manner based upon educational and pedagogical foundations, and a genuine desire on the employers' part for a collaborative partnership (Lashley, 2010; Juznic \& Pymm, 2011). So while there is acknowledgment in the academic literature that reflective practice is good for the student, it is unclear to what extent this reflective need is understood or appreciated by industry work experience providers. Conversely, in creating partnerships with industry it is important to ascertain, understand and appreciate the needs of industry in their employment of students.

Griffiths and Guile (2003, p. 60) talk about the complex and dynamic nature of language (knowledge), acknowledging that the sharing of information is complex and "not one of simple transmission and repetition". This complex dynamic is a basis for creativity, innovation and entrepreneurship and sustainability as new competencies. The embedding of these new competencies can be viewed as a new paradigm in education design (Matheson, 2006). Furthermore, these emerging competencies are necessary to facilitate the increasing number of strategic functions that events play (Allen et al. 2011; Jago \& Deery, 2010) and are needed in an environment of rapid social and technological change and in light of the new dynamics of consumer led choice (Talwaret al. 2010).

The need to enhance capacity in the workforce and the community, drive ongoing pedagogical investigation and skills improvement required for facilitating sustainable innovations in the rapidly changing (and competitive) working and leisure environment are recognised in this document. Each of these needs are, it is proposed here, drivers for developing the changing competencies of students and staff.

\section{METHODOLOGY}

Investigation of event management competencies is an ongoing line of enquiry pursued by the authors (Junek et al. 2009; Lockstone et al. 2008; Mair et al. 2009). In this analysis - as a scoping exercise for curriculum design of event management programs - an interpretative approach has been taken. Insight is sought by reference to a range of stakeholders in recognition of the need for the curriculum to be viewed with an open mind and collaboratively (Tribe, 2001). The teaching staff involved in the program play a pivotal role in offering up their personal reflections.

A case study approach is taken as it was thought to be appropriate to the interpretative framework of the study. As the case study draws both from people's experience and from practice it offers findings closely linked to the context in which it is based (Cohen, Manion, \& Morrison, 2000; Yin, 2003).

This context specific research methodology allows a depth of knowledge that is both supportive of, and necessary for, the growth of understanding in human behaviour (Flyvbjerg, 2006). It is an important research tool and is accepted as one particularly important in enriching the field of teacher education inquiry (Zeichner, 2007).

\section{DISCUSSION}

The responses to and challenges associated with embedding emerging competencies in event management education are discussed in turn. Except where indicated otherwise, these are discussed with reference to the core teaching program, the Bachelor of Business specialising in Event Management, offered at Victoria University, Melbourne, Australia.

\section{Challenges and opportunities in a rapidly changing event management arena}

While specialist knowledge, technological know-how and industry assimilation are vital to the employability of our students and their development, it must also be recognised that knowledge per se is the most important currency available in a world changing at an increasingly rapid rate. Reference here can be made to two strategic directives of Victoria University that reflect this and influence the design of programs to the extent that they should:

1. "Enrich student learning practice with greater connections between theoretical knowledge and application in realistic workplace and community contexts. 
2. Encourage staff to develop creative and innovative approaches to learning, teaching and relationship building through collaboration, knowledge sharing and engagement with stakeholders" (Victoria University, 2010, p. 1).

Griffiths and Guile (2003) recognise the mediating capacity of work experience and the way it can be made to aid students to "re-situate" their learning, i.e. rather than just coach students to work in any given situation it should allow students to see the benefits of working collaboratively with others and, where possible, facilitate skills which can cross professional and social boundaries' and encourage creative and entrepreneurial thinking. To do so it is important that students do not just get from their work a set of tasks to be repeated but that they also gain insight into the inter-connective nature of development. Work integrated learning therefore seeks to ensure an authentic learning experience: one which - as this paper goes on to discuss, will encourage both reflective, and suitably forward, thinking. The event management program at Victoria University integrates with industry on many levels to facilitate and encourage a community of (deep) thinking (Junek et al. 2009). For brevity this integrated effort is summarised below in Table 1.

\section{INSERT TABLE 1}

The challenges and opportunities specifically associated with meeting emerging event management knowledge needs and competencies are discussed in the remainder of this article. Competencies identified as being of key importance in facilitating the increasing number of strategic functions that events play, in an environment of rapid social and technological change, include sustainable development, creativity and innovation, ethics and networking. These acknowledge and relate to the essential characteristics of education for sustainable development as defined by UNESCO (2005).

Further, in the event management research literature, competencies are highlighted with reference to a "new sustainable and responsible events paradigm" (Getz, 2009, p. 37). This view is echoed in emergent business management research which charts increasing recognition of management practice needing to align to sustainable development, and creativity and innovation acting as conduits of good practice towards sustainability. Importantly, while education must enhance the current needs of the event industry, it should also support and encourage emerging best practice.

In their exploratory research comprising depth interviews with festival directors from the UK and Australia, Ensor, Robertson and Ali-Knight (2011) found that leaders gave environmental and social sustainability a much lower value than their other managerial goals. Similarly, Mair (2011) reflects on the failure of managers of business events to address environmental issues (most particularly their contribution to global warming). Both articles reiterate the significance of this skill set for the event business environment. As such these authors are merely confirming what is already recognised in the broader business management environment (Gupta, et al. 2010; Smit \& Wandel, 2006), i.e. that negating and responding to negative impacts is a managerial process as well as a result. It should be viewed as a requirement rather than a pragmatic addition.

Sustainable development is understood and applied within the event management learning environment at Victoria University. Principally this is exercised in the new unit of study 'Sustainable Operations'. Student, industry and staff engagement has reinforced the learning environment of the subject through the integration of industry seminars in which three or four representatives from industry present and respond to student questions on a theme pertinent to the developing and changing nature of sustainability and its related management practice. As a lynch pin subject, the learning objectives relating to sustainable operations progress through other event management specialist units of study, inclusive of 'Business Events', 'Event Evaluation and Legacy' and 'Event Creation and Design'.

Importantly, creativity is seen as being related to and not separate from sustainable development, i.e. that it supports the transitional, adaptive and innovation skills that it requires. The connection between creative capacity and sustainable development is covered extensively (Griffiths \& Guile, 2003; Matheson, 2006; Presbury \& Edwards, 2005; Slahova et al.2007) and spans a number of education disciplines (Salite, 2002).

In reference to festival event forms, Getz and Anderson (2008) highlight adaptability as a vital component of event organization which aids sustainability. In short, in employment the capacity 
to adapt professional plans and career directions to correspond to changing or new circumstances is highly important (Savickas, 1997; Rottinghaus, Day \& Borgen, 2005). The complex nature of organised events, the pulsating effect of staff movements (Toffler, 1990; Hanlon \& Jago, 2011) and the financial, and, on occasion, physical risks they impart can make their management more volatile than a great many other industries. Accordingly, within the event working environment adaptability is vitally important. It is certainly a managerial context to which event management students at Victoria University are made aware in their contemplation of sustainability. Furthermore, guest speakers are encouraged to highlight related issues from their own working experience to reinforce this knowledge.

Clearly related to adaptability, creativity and innovation are key competencies in the organisational structure of business today (Amabile et al. 2006; DiLiello \& Houghton, 2008). It is important that creativity and innovation are seen as separate but related elements. So while creativity relates more particularly to the generation of ideas (Berridge, 2010), innovation is the process of their application (Ensor, Cottam, \& Band, 2001; Ensor et al. 2011). This to say that together they are about forming ideas, then designing applications and testing and applying them in the context in which they work. Assimilating this process in the teaching and learning framework is undertaken in a number of ways.

Importantly, the event management teaching team have included design education initiatives to facilitate the development of creative thinking with clear reference to the events working context (and the perceptions of industry).

"A creative process anticipates the creation of a new product that heavily depends, on the one hand, on the uniqueness of a person, but, on the other hand, is conditioned by the material itself, happenings, people and circumstances of life" (Slahova et al., 2007, p. 143).

Nonetheless, ensuring that this is understood as being the basis of innovation is more difficult to apply in the semi-vocational learning environment of higher education and in the field of management (and its study). Historically, it has been difficult to get industry to engage in this line of thought. In the minds of industry and (by association) students, creativity may be conceived as an element that draws students' away from the skills of analysis and problem solving. The unit 'Event Creation and Design' is about developing knowledge capacity and attaining new skills to develop and manage a process of creativity through to its application (innovation) for organised events. Importantly, it is also about engaging students and industry in activities that highlight the deeper role creativity has in ensuring peer and group review skills. This is to say it is about problem solving and issue awareness and is thus expanding knowledge of the wider and inter-related issues surrounding context and stakeholder consultation. The importance of this capacity is recognised in related research (Berridge, 2010; DiLiello \& Houghton, 2008; Ensor, Robertson \& Ali-Knight, 2007; Gibson \& Kong, 2005; Hede \& Stokes, 2009) but not always by industry.

As with the unit of study Sustainable Operations, the consultative nature of the assessment in the unit 'Event Creation and Design' aids the capacity development of the key stakeholder groups, i.e., students, industry and teaching staff (see Table 2).

\section{INSERT TABLE 2}

In creating units that are constructed to facilitate an understanding of the significance of (and role for) knowledge and creativity, the pedagogical processes and practical exercises are developed together. Students learning and their capacity to apply and reflect upon this is enhanced by industry engagement, by instruction in methodological process and, further, by involvement in group work (formative and summative); allowing students to elicit their own methodological process and apply them to their event idea.

Significantly, the extent of innovation is controlled, not only by knowledge that is readily available but also by the capacity for people to think together, i.e. network. The capacity of a network to be innovative is determined not only by the extent to which individuals contribute creatively but also by the extent to which network participants as a whole contribute to enhance that creativity. This often requires a mindset change (Matheson, 2006; Power, 2010; Selart et al., 2008; Slahova et al., 2007; Zeichner, 2007). 
Accordingly, the event ideas that the student groups create (set in an assessment parameter) are shared most particularly with emerging group leaders (those with highest grades) from each tutorial group with an industry panel (see Table 2) - each stakeholder involved enjoying the high quality of the other. In future these exchanges will be videotaped to allow other student groups to further understand the dynamics of group collaboration and mentoring. Similarly, engagement with social media as another platform for this engagement is being considered.

Networking is a conscious and a largely self-managed activity by individuals to form, develop and enhance professional (and/or personal) relationships for the sake of mutual career development. It is well accepted in the day-to-day activity of most professionals. There is a very large body of literature subsequent to this. However, at an individual level, networking is also a vital skill set required for progression, both within an organisation and in the professional environment generally (de Janasz \& Forret, 2008). In the tourism management discipline, inter-organisational learning, i.e., network relations, are recognised as instrinsic to the innovative and competitive capacity of an organization (Denicolai, Cioccarelli \& Zucchella, 2010). In the event tourism context, Stokes (2007) identified these as collaborative partnerships, relationship marketing, networks of sports events, and integrated relationship marketing. Given that the networks are so significant for the strategic development of events (whether in the fields of business, culture, arts or community), it is all the more imperative that students are given the opportunity to become aware of and develop this skill set. Accordingly, project based activities, guest speakers, workshops and roleplay (based on stakeholder positions) are integrated into a number of units, most particularly Business Events and Event Creation and Design.

Social media and its use within the wider context of the Internet and online learning is an increasingly important aspect of education (Greenhow, 2011; Scearce, Kasper \& Grant, 2010), as it is in business. Whilst the Victoria University example is at the early stages of adoption in terms of embedding social media in the event management course curriculum, its use as a platform for dissemination of information by staff as part of a faculty wide strategy of engagement is well established. Most commonly animated through the well-known platform Facebook, the application is maturing from its initial use as notice board to one for collaborative communications and networking.

The dynamics of collaborative communication requires specialist knowledge. Much of this is held within the school team or the broader faculty. However the future context of learning will most certainly incorporate other social media, in particular those that enhance new forms of collaborative intelligence. As the business event sector, in particular, copes with a market that is moving away from reliance on traditional Internet (web) based activity and towards an increasingly more portable and handheld media, each with greater capacity for self-management and collaborative integration (Talwar et al., 2010), so too students of event management need to move from being mere users to becoming innovators. This offers both a challenge and an opportunity for the the education sector in event management education to cater to these emerging competencies.

\section{Further enhancement of technical proficiencies of students}

In addition to embedding competencies within the curriculum, technical skills, including proficiency in information technology skills related to event management, are an integral part of the emerging skill set expected by the events industry given its enhanced focus on professionalisation in recent years (Jago \& Deery, 2010; Talwar et al. 2010).

With the use of information technology identified as underpinning sustainable education (Spangenberg, 2005), a key question surrounds the capacity for technology to be grounded in the context of individual subjects. Within the event management degree program, as in other degree programs, Victoria University seeks to promote capacity enrichment through the embedding of technology in management education. Students are exposed to a number of event industry software programs in order to enhance their technical proficiency relevant to their eventual work environment. In the unit of study 'Business Events', students are tutored in the use of Eventspro as an individual and group assessment tool. This specialised database software allows students to become familiar with the process of creating databases for individual events, registering attendees, booking their accommodation and social functions and other related tasks necessary for the successful management of business events. 
In the 'Event Evaluation' unit students use a dedicated software program designed to evaluate the economic performance of events. They generate an event evaluation questionnaire using the software as part of the major assignment for the unit and subsequently discuss the details of how they plan to administer their survey at a fictional event.

In the unit of study 'Event Creation and Design' the students are introduced to a range of presentation software, including Spiderscribe (a cloud based platform in which students can collaborate - in real time - on mindmapping and event design plan frameworks), Prezi (a cloud based presentation tool) and Googlesketchup (an online freeware 3D design presentation tool). Students have the opportunity to use these tools in their event design submission, as part of a design pitch to a fictional client group. Importantly there are versions of this software free to download, thus students have the flexibility to develop their skills at their chosen pace during and after the unit. Spiderscribe, in particular, allows the students to collaborate online at the same time on initial creative ideas and also on their innovative design. As such it introduces students to a collaborative networking process, previously identified as an important emerging competency.

\section{FUTURE AREAS OF RESEARCH AND COMMENT}

The nature of what is discussed as being new knowledge needs and competencies indicates the interdisciplinary nature of many of these, particularly so when dealing with sustainability (Dale \& Newman, 2005). The work of Deery and Jago (BECA, 2010) indicates there is some awareness of this. The application of these competencies to higher education teaching (rather than research) requires greater discussion. Similarly the potential reticence (or lack of knowledge) by the event industry to engage with this learning process has to be understood. Activities and engagements with the event industry shown in the case study indicate that environments can be created to make this happen.

Technical proficiency is acknowledged by our event industry contacts as an important attribute when considering our students for employment. The rapid development of the technological environment is, thus, an ongoing challenge when both time and money is required to ensure both understanding and capacity building in this area.

Creativity, and the need for more creative capacity in any given city is widely recognised (UNCTAD, 2008). While there are discussions as to which industries are included in creative capacity building (Flew \& Cunningham, 2010), academic institutions cannot fail to recognise creativity as an important element of economic competitiveness and sustainability. It is also the duty of academic institutions to initiate conversation and relationships with industry to ensure that students as prospective employees can benefit from the heightened potential to utilise creativity in their application to, and analysis and reflection of, their working role.

In establishing an interpretative process for the analysis in this article, reference was made to John Tribe's (2001) own conclusion regards looking at curriculum for tourism. He states, "Curricula are forged by men and women and for men and women, and so curriculum analysis must take account of a complex series of interpenetrations between the conceiver, the conceived, the conceived for whom, and the conceived for what purposes" (p. 247). Thus while it can be suggested that it is the duty of industry to adapt to change, this does not negate the fact that higher education can lead by example rather than being concerned only with reacting to their prospective partners in student learning. In event education, an area still seeking to gain ground in academic legitimacy, this may, however, be a challenge.

\section{CONCLUSION}

Investigation into event management competencies is, as stated earlier, an ongoing one. The challenges of embedding the competencies of sustainability, creativity and innovation and networking have been highlighted in this article. These competencies are (and will be) vital for graduate students, both for their own employability and for future needs of the events industry. In the context of authentic learning, the embedded competencies aim to provide students with knowledge and skills to enable them to not only work successfully within the events industry, but also to lead it in an increasingly challenging environment. It will become more important for students to have not only the 
"skills and competencies needed to succeed in today's workplace" (Fook \& Sidhu, 2010, p. 154) but to be well equipped for the changing nature of the events, and in fact, many other industries. Given the emerging nature of research on event management education the current discussion should be considered tentative towards an agenda for future study.

There are sufficient gaps in current knowledge to expand the study to incorporate other universities currently offering event management as an undergraduate or postgraduate degree or to examine cross-cultural differences by investigating education models and student populations from other countries.

\section{REFERENCES}

Alderman, B. \& Milne, T. (2005). A model for work-based learning. Lanham, MD: Scarecrow Press. Allen, J., W. O’Toole, R. Harris, \& McDonnell, I. (2011). Festival and special event management (5th ed.). Milton, Queensland: John Wiley and Sons.

Amabile, T. M., Conti, R., Coon, H., Lazenby, J., \& Herron, M. (1996). Assessing the Work Environment for Creativity. The Academy of Management Journal, 39(5), 1154-1184.

Beaven, Z., \& Wright, R. (2006). Experience! experience! experience! Employer attitudes to arts and event management graduate employability. International Journal of Event Management Research, 2, 17-24.

Bennet, G., Henderson, R., \&Drane, D. (2003). Student experiences with service-learning in sport management. The Journal of Experiential Education, 26(2), 61-69.

Berridge, G. (2010) Event pitching: The role of design and creativity. International Journal of Hospitality Management, 29(2), 208-215.

Boud, D. \& Falchikov, N. (2005). Redesigning assessment for learning beyond higher education. Research and Development in Higher Education, 28, 34-41.

Brown, J.S., Collins, A. \& Duguid,P. (1988). Situated cognition and the culture of learning. Palo Alto CA: Institue for Research on Learning.

Bruner, J. (1996). The culture of education. Cambridge, MA: Harvard University Press.

Christou, E. (2002). Revisiting competencies for hospitality management: Contemporary views of the stakeholders. Journal of Hospitality and Tourism Education, 14(1), 25-32.

Cohen, L., Manion, L., \& Morrison, K. (2000). Research methods in education. London: Taylor \& Francis Group.

Dale, A., \& Newman, L. (2005). Sustainable development, education and literacy. International Journal of Sustainability in Higher Education, 6(4), 351-362.

Daruwalla, P., \& Fallon, W. (2005). Experiential learning in events management education: Developing reflective practitioners. In J. Allen (Ed.), Impacts of events: Proceedings of the International Events Research Conference (pp. 587-603). Sydney, Australia: University of Technology Sydney.

deJanasz, S. C., \&Forret, M. L. (2008). Learning TheArt of Networking: A Critical Skill for Enhancing Social Capital and Career Success. Journal of Management Education, 32(5), 629650.

Deci, E. L., Koestner, R., \& Ryan, R. M. (1999). A meta-analytic review of experiments examining the effects of extrinsic rewards on intrinsic motivation. Psychological Bulletin, 125(6), 627.

Denicolai, S., Cioccarelli, G., \& Zucchella, A. (2010). Resource-based local development and networked core-competencies for tourism excellence. Tourism Management, 31(2), 260-266.

Diamond, S., Middleton, A. \& Mather, R. (2011). A cross-faculty simulation model for authentic learning. Innovations in Education and Teaching International, 48 (1), 25-35.

DiLiello, T. C., \& Houghton, J. D. (2008). Creative potential and practised creativity: Identifying untapped creativity in organizations. Creativity \& Innovation Management, 17(1), 37-46.

Eisenberger, R., Pierce, W. D., \& Cameron, J. (1999). Effects of reward on intrinsic motivationnegative, neutral, and positive: Comment on Deci, Koestner, and Ryan (1999). Psychological Bulletin, 125, 677-691. 
Eisenberger, R., \& Shanock, L. (2003). Rewards, intrinsic motivation, and creativity: A case study of conceptual and methodological isolation. Creativity Research Journal, 15(2), 121-130.

Ensor, J., Pirrie, A., \& Band, C. (2006). Creativity work environment: do UK advertising agencies have one? Management, 9(3), 258-268.

Ensor, J., Robertson, M., \& Ali-Knight, J. (2007). The dynamics of successful events - the experts' perspective. Managing Leisure, 12(2/3), 223-235.

Ensor, J., Robertson, M., \& Ali-Knight, J. (2011). Eliciting the dynamics of leading a sustainable event: key informant responses Event Management, 15(4), In print.

Flew, T., \& Cunningham, S. (2010). Creative Industries after the First Decade of Debate. The Information Society: An International Journal, 26(2), 113 - 123.

Flyvbjerg, B. (2006). Five Misunderstandings About Case-Study Research. Qualitative Inquiry, 12(2), 219-245.

Fook, C.Y. \& Sidhu, G.K. (2010). Authentic Assessmnet and Pedagogical Strategies in Higher Education. Journal of Social Sciences, 6 (2), 153-161.

Getz, D. (2008). Event tourism: Definition, evolution and research. Tourism Management, 29, 403428.

Getz, D. (2009). Policy for sustainable and responsible festivals and events: institutionalization of a new paradigm. Journal of Policy Research in Tourism, Leisure and Events, 1(1), 61 - 78.

Getz, D., \& Andersson, T. (2008). Sustainable festivals: on becoming an institution. Event Management, 12(1), 1-17.

Gibson, C., \& Kong, L. (2005). Cultural economy: A critical review. Progress in Human Geography, 29(5), 541-561.

Greenhow, C. (2011). Online social networks and learning.On the Horizon, 19(1), 4-12.

Griffiths, T., \& Guile, D. (2001). Learning through work experience. Journal of Education and Work, 14(1), 113-131.

Griffiths, T., \& Guile, D. (2003). A connective model of learning: The implications for work process knowledge. European Educational Research Journal, 2(1), 56-73.

Guilkers.J., Bastiaens, T. \& Kirschner P. (2006). Authentic assessment, student and teacher perceptions:The practical value of the five dimensional framework. Journal of Vocational Education and Training, 3 (58), 337-357.

Gupta, J., Termeer, C., Klostermann, J., Meijerink, S., van den Brink, M., Jong, P., et al. (2010). The Adaptive Capacity Wheel: a method to assess the inherent characteristics of institutions to enable the adaptive capacity of society. Environmental Science \& Policy, 13(6), 459-471.

Hanlon, C., \& Jago, L. (2011).Staffing for successful events - having the right skills in the right place at the right time. In S. Page \& J. Connel (Eds.), The Routledge Handbook of Events (pp. 304315). Oxon: Routledge

Harvey, L. \&. Locke, W. (2002). Enhancing employability, recognising diversity:making links between higher education and the world of work. Retrieved December 15, 2011, from Universities UK:

http://www.qualityresearchinternational.com/esecttools/relatedpubs/enhancingemployabilityre cdiversity.pdf

Hede, A.-M., \& Stokes, R. (2009). Network analysis of tourism events: An approach to improve marketing practices for sustainable tourism. Journal of Travel \& Tourism Marketing, 26(7), $656-669$.

Jago, L. \&Deery, M. (2010). Delivering innovation, knowledge and performance: The role of business events. NSW: Business Events Council of Australia (BECA).

Junek, O., Lockstone, L., \& Mair, J. (2009). Two perspectives on event management employment: Student and employer insights into the skills required to get the job done! Journal of Hospitality and Tourism Management, 16(1), 120-129.

Junek, O., Lockstone, L., \& Osti, L. (2007). Event management education: The students' perspective. Proceedings of the $4^{\text {th }}$ International Event Research Conference and $2^{\text {nd }}$ Event Education and Research Network Australasia symposium. Melbourne: Victoria University \& Australian Centre for Event Management, UTS.

Juznic, P. \& Pymm, B. (2011). Students on placement: A comparative study. New Library World, $112(5 / 6), 248-260$. 
Lashley, C. (2010). University challenge: Sharing some experiences of engaging with industry. International Journal of Contemporary Hospitality Management, 23(1), 131-140.

Lave, J. \& Wenger,E. (1991). Situated learning:legitimate peripheral participation. Cambridge: Cambridge University Press.

Lee, K. M., Lee, M. J., \& Kim, H. J. (2008).Comparing perceptions of event management curriculum: A factor-correspondence analysis. Event Management, 12,67-79.

Lei, S. A. (2010). Intrinsic and extrinsic motivation: Evaluating benefits and drawbacks from college instructors' perspectives. Journal of Instructional Psychology, 37, 153-160.

Lockstone, L., Junek, O., \& Mair, J. (2008). Experiential learning in event management education: Do industry placements in degree courses complement jobs available in the events industry? In S. Richardson, L. Fredline, A. Patiar \& M. Ternel (Eds.), Tourism and hospitality research, training and practice: "Where the 'bloody hell' are we?"Proceedings of the 2008 CAUTHE conference. Gold Coast: Griffith University.

Mair, J., Junek, O., \& Lockstone, L. (2009). Event education and engagement with industry: Is it worth it? In J. Carlsen, M. Hughes, K. Holmes \& R. Jones (Eds.), See change: Tourism \& hospitality in a dynamic world. Proceedings of the 2009 CAUTHE conference. Fremantle: Curtin University of Technology.

Mair, J. (2011). Events and climate change: an Australian perspective. International Journal of Event and Festival Management, 2(3), 245-253.

Matheson, B. (2006). A culture of creativity: design education and the creative industries. Journal of Management Development, 25(1), 55-64.

McDonald, D., \& McDonald, T. (2000). Festival and event management: An experiential approach to curriculum design. Event Management, 6(1), 5-13.

Moscardo, G., \& Norris, A. (2004).Bridging the academic practitioner gap in conference and events management: Running events with students. Journal of Convention and Event Tourism, 6(3), 47-62.

Mueller, J. (2006). Authentic Assessment Toolbox. Retrieved December 14, 2011, from http://jfmueller.faculty.noctrl.edu/toolbox/

Power, A. (2010). Community engagement as authentic learning with reflection: Special edition on service learning. Issues in Educational Research, 20 (1), 57-62.

Power, S. J. (2010). Career management tactical innovations and successful interorganizational transitions. Career Development International, 15(7), 664-686.

Presbury, R., \& Edwards, D. (2005).Incorporating sustainability in meetings and event management education. International Journal of Event Management Research, 1(1), 30-45.

Rottinghaus, P. J., Day, S. X., \& Borgen, F. H. (2005). The career futures inventory: A measure of career-related adaptability and optimism. Journal of Career Assessment, 13(1), 3-24.

Salite, I. (2002).Teachers views on the aim of education for sustainable development. Journal of Teacher Education and Training, 1, 68-80.

Savickas, M. L. (1997). Career adaptability: An integrative construct for life-span, life-space theory. Career Development Quarterly, 45, 247-259.

Scearce, D., Kasper, G. \& Grant, H. M. (2010).Working wikily. Stanford Social Innovation Review. Retrieved June 3, 2011, from www.ssireview.org/articles/entry/working_wikily

Schwartz, B. (2009). Incentives, choice, education and well-being. Oxford Review of Education, 35(3), 391-403.

Selart, M., Nordström, T., Kuvaas, B., \& Takemura, K. (2008). Effects of reward on self-regulation, intrinsic motivation and creativity. Scandinavian Journal of Educational Research, 52(5), 439-458.

Silvers, J. R., Bowdin, G. A. J., O'Toole, W. J., \& Nelson, K. B. (2006). Towards an international Event Management Body of Knowledge (EMBOK). Event Management, 9, 185-198.

Slahova, A., Savvina, J., Cacka, M., \& Volonte, I. (2007). Creative activity in conception of sustainable development education. International Journal of Sustainability in Higher Education, 8(2), 142-154. 
Smit, B., \& Wandel, J. (2006). Adaptation, adaptive capacity and vulnerability. Global Environmental Change, 16(3), 282-292.

Spangenberg, J. (2005). Will the information society be sustainable? Towards criteria and indicators for a sustainable knowledge society. International Journal of Innovation and Sustainable Development, 1(1), 85-102.

Stein, S.J.,Isaacs, G. \& Andrews, T. (2004). Incorporating authentic learning experiences within a university course. Studies in higher education, 29 (2), 239-259.

Sururov, A., \& Van de Ven, J. (2006). Discretionary rewards as a feedback mechanism. Amsterdam Center for Law \& Economics. Mimeo: University of Amsterdam.

Tochon, F. (2000). When authentic experiences are 'enminded' into disciplinary genres:crossing biographic and situated knowledge. Learning and instruction, 10 (4), 331-359.

Tribe, J. (2001). Research paradigms and the tourism curriculum. Journal of Travel Research, 39(4), $442-448$.

Talwar, R., Hancock, T., Yeomans, G., \& Padgett, P. (2010). Convention 2020: The future of exhibitions, meetings and events. Retrieved May 4, 2011, from www.fastfuture.com

Toffler, A. (1990). Power Shift. New York: Bantan Books.

United Nations Committee on Trade, Aid and Development. (2008). Creative economy report 2008. Geneva: UNCTAD.

UNESCO (2005), United Nations Decade of Education for Sustainable Development (2005-2014): International Implementation Scheme, October ED/DESD/2005/PI/01, UNESCO, Paris, Retrieved, 20 May, 2011 from: http://unesdoc.unesco.org/images/0014/001486/148654e.pdf

Van Oers,B. \& Wardekker,W. (1999). On becoming an authentic learner: semiotic activity in the early grades. Journal of curriculum studies, 31 (2), 229-249.

Victoria University. (2010). Learning in the workplace and community. Retrieved May 8, 2011, from www.vu.edu.au

Yin, R. K. (2003). Applications of case study research (2nd ed.). London: Sage Publications Inc.

Zeichner, K. (2007). Accumulating knowledge across self-studies in teacher education. Journal of Teacher Education, 58(1), 36. 
Table 1Multiple levels of industry integration in event management education

\begin{tabular}{|l|l|l|}
\hline Engagement type & Engagement format & Engagement environment \\
\hline Industry speakers (traditional) & Formal lecture/panel style & Open \\
\hline Industry speakers (ex-students) & Lecture/Q\&A session & Open \\
\hline Industry speakers unit specific & Presentation/Q \& A & Open \\
\hline Industry seminar (theme specific) & Networking lunch & Student input (oral) \\
\hline Industry panels (unit specific) & Feedback on student work & Student input (written and oral) \\
\hline Industry mentor (unit specific) & Support student group work & Student input (written and oral \\
\hline $\begin{array}{l}\text { Engagement with event industry } \\
\text { associations }\end{array}$ & Networking/membership & Teaching staff input \\
\hline $\begin{array}{l}\text { Industry awards/bursaries } \\
\text { (industry led) }\end{array}$ & $\begin{array}{l}\text { Open competitive } \\
\text { (Individual) }\end{array}$ & Student input (written and oral) \\
\hline Industry awards (unit specific) & Unit competitive (Group) & Student input (written and oral) \\
\hline Industry awards (unit/degree) & $\begin{array}{l}\text { National competitive } \\
\text { (Group) }\end{array}$ & Staff input \\
\hline Work integrated learning & Industry grounded & $\begin{array}{l}\text { Work experience and academic } \\
\text { reflection }\end{array}$ \\
\hline
\end{tabular}

Table 2: Industry engagement initiatives in event management education: Event Creation and Design

\begin{tabular}{|l|l|l|}
\hline Engagement type & Engagement format & Engagement environment \\
\hline Industry speakers unit specific & Lecture/ Q\&A session & Open \\
\hline Industry panels (unit specific) & $\begin{array}{l}\text { Feedback on best student } \\
\text { work (Industry/Teaching } \\
\text { staff) }\end{array}$ & $\begin{array}{l}\text { Teaching Staff (organisation)/ } \\
\text { Student input (written and oral) }\end{array}$ \\
\hline
\end{tabular}

